\title{
Volatilization of ammonia in tropical soil with different moisture after application of polymer-coated urea
}

\author{
Mário Miyazawa ${ }^{1}$, Luciano Grillo Gil ${ }^{* 1}$, Antonio Costa ${ }^{1}$, Roberto dos Anjos Reis Júnior ${ }^{2}$, Íris Tiski ${ }^{2}$ \\ ${ }^{1}$ Soil area, Agronomic Institute of Paraná (IAPAR), Londrina, State of Paraná, CEP 86.047-902, Brazil \\ ${ }^{2}$ Wirstchat, Londrina, State of Paraná, Brazil
}

*Corresponding author: Iggil@iapar.br

Abstract

\begin{abstract}
Nitrogen fertilizer has a significant participation in the cost of agricultural production. It is less efficient agronomically and requires more studies to find strategies to be absorbed by crop. Polymer-coated urea is an alternative for the production of increased efficiency fertilizers. Validation of this technology should be performed for safe adoption in agriculture. The objectives of this work were to evaluate the nitrogen losses by volatilization of ammonia and the nitrogen contents in the nitric $\left(\mathrm{N}-\mathrm{NO}_{3}{ }^{-}\right)$and ammoniacal $\left(\mathrm{N}-\mathrm{NH}_{4}{ }^{+}\right)$forms in the tropical soil after application of urea sources. Three greenhouse experiments with different soil moisture conditions were carried out after application of urea, urea treated with NBPT and urea coated with Policote polymer as treatments. Then volatilization of ammonia, $\mathrm{N}-\mathrm{NO}_{3}{ }^{-}$and $\mathrm{N}-\mathrm{NH}_{4}{ }^{+}$contents in the soil was evaluated. The volatilization of ammonia was observed after using Policote-coated urea, which was similar to urea treated with NBPT. However, both of which were lower than that observed under urea application. In dry or very humid soil, the ammonia volatilization rate was low. The reduction of the volatilization of ammonia in the soil with Policote-coated urea was related on the humidity, whereas more effective when the conditions were more propitious to the volatilization of ammonia. The Policote-coated urea increased the content of $\mathrm{N}-\mathrm{NH}_{4}{ }^{+}$in the tropical soil compared to urea. The content of $\mathrm{N}^{-\mathrm{NH}_{4}}{ }^{+}$in the soil was higher than $\mathrm{N}-\mathrm{NO}_{3}{ }^{-}$after application of fertilizers due to the low organic matter content.
\end{abstract}

Keywords: Nitrogen reactions; N-ammoniacal; N-nitric; Policote; oxisoil.

Introduction

Nitrogen $(\mathrm{N})$ is one of the mineral elements required in greater quantity by plants (Souza and Fernandes, 2006) and also what mostly limits agricultural production. Nitrogen is a component of chlorophyll and essential for photosynthesis. It is also the basic element of proteins, including the genetic material such as DNA and RNA.

Nitrogen fertilizers such as urea require strategies that increase its efficiency of use by crops due to its necessity of use in agriculture, its significant participation in the cost of production and its low efficiency. Baligar et al. (2001) concluded that increasing nitrogen use efficiency (NUE) is vital to increase crop productivity and quality, reduce nitrogen use, and improve soil, water and air quality. Among the strategies to increase the NUE, the use of increased efficiency fertilizers (IEF) which contains aggregate technologies stands out. They control the release of nutrients or stabilize their chemical reactions in the soil, increasing their availability to plants (AAPFCO, 1997).

The IEF can be classified into three classes: slow release, controlled release and stabilized. Controlled and slow release fertilizers are those from which nutrient release into the environment occurs in more or less slow and controlled manner (Shaviv, 2000). Stabilized nitrogen fertilizers contain some additives capable of inhibiting the nitrogen reaction in the soil in some undesirable form (AAPFCO, 1997). Thus, slow/controlled release fertilizers act when the nutrient is available to the plants, while stabilized fertilizers act on the chemical form, in which the nutrient is made available to the plants. Stabilized fertilizers control the dynamics of chemical reactions of nitrogen in the soil, involving the processes of ammonia volatilization, nitrate leaching and nitrous oxide emission. These processes, besides reducing the efficiency of the nitrogen fertilization, bring environmental damages. Of these processes of $\mathrm{N}$ loss, the most studied is volatilization of ammonia, especially urea application. Losses by volatilization of ammonia due to nitrogen fertilization have been reported in the order of $31.2 \%$ (Cancellier, 2013), 11\% (Rochette et al., 2013), 27\% (Schwenke et al., 2014) and 25\% (Li et al., 2015).

The benefits of reduction in ammonia volatilization and nitrate leaching have been widely discussed. However, the benefits of promoting a higher $\mathrm{N}$-ammoniacal supply to the plants, promoted by certain stabilized nitrogen fertilizers are scarce. $\mathrm{N}$-nitric $\left(\mathrm{N}^{-\mathrm{NO}_{3}}{ }^{-}\right)$is the predominant mineral form of $\mathrm{N}$ in aerated soils (Sangoi et al., 2003; Carelli et al, 2006), due to the rapid oxidation of $\mathrm{N}$-ammoniacal $\left(\mathrm{N}-\mathrm{NH}_{4}{ }^{+}\right)$to $\mathrm{N}$ $\mathrm{NO}_{3}^{-}$by the nitrifying bacteria. The $\mathrm{N}_{-} \mathrm{NH}_{4}{ }^{+}$contents found in agricultural soils are generally 10-1000 times lower than $\mathrm{N}$ $\mathrm{NO}_{3}{ }^{-}$(Marschner, 1995). Thus, $\mathrm{N}-\mathrm{NO}_{3}{ }^{-}$is the predominant form available for plant absorption when using conventional nitrogen fertilizers and slow/controlled release. It is known that cationic nutrients, such as $\mathrm{N}^{-\mathrm{NH}_{4}}{ }^{+}$, are absorbed 
passively, without energy cost (Marschner, 1995), while anionic nutrients such as $\mathrm{N}^{-\mathrm{NO}_{3}}{ }^{-}$are absorbed with metabolic cost. About $45 \%$ of the ATPs reserve in the root hair cells can be consumed with the active absorption of the anions (Carvalho et al., 2008). The preferential absorption of ammonium compared to nitrate can be advantageous, offering lower metabolic energy cost and the not necessary nitrate reductase action in the roots (Grespan et al, 1998).

Studies comparing the performance of urea-coated polymers with respect to common urea have not been conclusive, because while there are reports pointing to advantages of the use of polymer-coated urea (Fan et al., 2004, Noellsch et al., 2009; Pereira et al., 2009; Wilson et al., 2009; Garcia et al., 2018; Ribeiro et al., 2016), others point inefficiency, compared to urea (Nelson et al. 2009; Cahill et al. 2010; Mckenzie et al. 2010; Civardi et al. 2011; Prando et al. 2013; Martins et al., 2014). Therefore, it cannot be concluded that any coating with polymers will result in the same result. Thus, validation studies of technologies using polymer coating for IEF production are necessary so that these fertilizers can be safely adopted in agriculture.

The objectives of this work were to evaluate the losses of nitrogen by volatilization of ammonia, the contents of $\mathrm{N}$ $\mathrm{NO}_{3}{ }^{-}$and $\mathrm{N}-\mathrm{NH}_{4}{ }^{+}$in the soil in response to urea sources.

\section{Results}

\section{Volatilization of ammonia in the soil with high humidity}

The accumulated volatilization of ammonia (AVA) was significantly influenced $(p<0.05)$ by the doses and sources of nitrogen during the evaluated days (Figure $1 \mathrm{a}$ and $1 \mathrm{~b}$ ). The control treatment (without use of $\mathrm{N}$ ), presented the lowest AVA (0.2 kg ha ${ }^{-1}$ at 18 days after application of $\left.\mathrm{N}\right)$. The largest AVAs were observed at the highest $N$ dose $(100 \mathrm{~kg}$ $\left.\mathrm{ha}^{-1}\right)$. At 18 days after fertilizer application, the AVA that observed for Policote-coated urea (U+P) at doses of 50 and $100 \mathrm{~kg} \mathrm{~N} \mathrm{ha}{ }^{-1}$ were $1.51 \mathrm{~kg} \mathrm{ha}^{-1}$ and $2.63 \mathrm{~kg} \mathrm{ha}^{-1}$, respectively; while these values increased to $2.71 \mathrm{~kg} \mathrm{ha}^{-1}$ and $3.63 \mathrm{~kg} \mathrm{ha}^{-1}$ under urea $(U)$, respectively. U+P reduced AVA by $44.3 \%$ and $27.5 \%$ when compared to $U$.

\section{Volatilization of ammonia at dry and low humidity soils}

The evaluations up to first irrigation ( $14^{\text {th }}$ day) showed no significant volatilization influenced by nitrogen sources (Figures $2 \mathrm{a}$ and $2 \mathrm{~b}$ ). In the period when the soil remained dry, the AVA was lower than $1.8 \mathrm{~kg} \mathrm{ha}^{-1}$, which is explained by the low soil moisture. There was a statistical difference between the treatments for AVA $(p<0.05)$ only in the evaluations from the 16th to the 23rd day. The control, without N, had the lowest AVA $\left(2.24 \mathrm{~kg} \mathrm{ha}^{-1}\right)$, while urea had the highest AVA $\left(54.3 \mathrm{~kg} \mathrm{ha}^{-1}\right)$. U+P and urea treated with NBPT (U+NBPT) presented AVA statistically equal to each other (20.3 and $17.3 \mathrm{~kg} \mathrm{ha}^{-1}$, respectively). The peak of volatilization was occurred on the $20^{\text {th }}$ day of evaluation (five days after irrigation), when urea was the fertilizer with the highest ammonia volatilization. Only on day $20^{\text {th }}$, ammonia volatilization with urea was $30.7 \mathrm{~kg} \mathrm{~N} \mathrm{ha}^{-1}(56.5 \%$ of AVA observed with urea). U+P (9.2 kg ha ${ }^{-1}$ ) and U+NBPT (9.1 kg $\mathrm{ha}^{-1}$ ) also showed a peak of volatilization at the same time as urea, but with a reduction of $70 \%$ in relation to volatilized ammonia in urea. In total, $36.2 \%$ of the $\mathrm{N}$ in urea was volatilized, while U+P and U+NBPT volatilized $13.5 \%$ and $11.5 \%$, respectively. The increased efficiency of fertilizers
(U+P and U+NBPT) caused AVA reductions of $62.6 \%$ and $68.1 \%$, respectively.

\section{$\mathrm{N}$-ammoniacal and $\mathrm{N}$-nitric in the soil}

The $\mathrm{N}-\mathrm{NO}_{3}{ }^{-}$content of the soil was not influenced by the treatments $(p<0.05)$. However, the incubation time was significant. The $\mathrm{N}^{-\mathrm{NO}_{3}}{ }^{-}$content was increased linearly with the incubation time, ranging from 9.0 to $23.7 \mathrm{mg} \mathrm{kg}^{-1}$ in the soil. The $\mathrm{N}^{-\mathrm{NO}_{3}}$ soil content was increased $1.05 \mathrm{mg} \mathrm{kg}^{-1}$ per day (Fig 3b). The soil $\mathrm{N}^{-\mathrm{NH}_{4}}{ }^{+}$content was significantly influenced by the sources $(p<0.01)$ and by the incubation

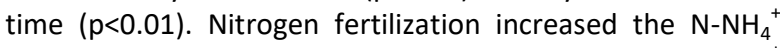

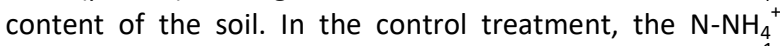
content was increased linearly from 11.8 to $35.7 \mathrm{mg} \mathrm{kg}^{-1}$, resulting in an increase of $1.5 \mathrm{mg} \mathrm{kg}^{-1}$ each incubated day

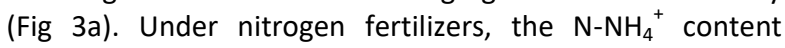
presented a quadratic response. Under urea and $\mathrm{U}+\mathrm{P}$, the maximum contents of $\mathrm{N}^{-\mathrm{NH}_{4}{ }^{+} \text {were } 222.1 \mathrm{mg} \mathrm{kg}}{ }^{-1}$ (at 9.9 days of incubation) and $234.1 \mathrm{mg} \mathrm{kg}^{-1}$ (at 10.6 days of incubation), respectively (Figure $3 a$ ).

\section{Discussion}

The process of volatilization of ammonia begins after the enzymatic hydrolysis of urea in the soil. However, soil moisture was the main factor that controlled volatilization. The soils with high humidity showed intensified dissolution and diffusion of urea, decreasing volatilization (Cabezas et al., 1997). In the first experiment, in spite of having a reduction of ammonia volatilization in the U+P treatment, the urea volatilization rate was low (around 5\%), due to the soil moisture dissolving and completely diffusing the urea through the soil.

In the second experiment, the dry soil had practically no volatilization, but when the soil was moist enough to start hydrolysis of the urea without diffusion, the volatilization rate was high and the urea volatilized more ammonia than the other treatments. There was ammonia volatilization of $36 \%$ in total applied to urea, similar values were observed by Cancellier (2013) and lower values were observed by Rochette et al. (2013), Schwenke et al. (2014) and Li et al. (2015).

The Policote-coated urea (U+P) and urea treated with NBPT $(\mathrm{U}+\mathrm{NBPT})$ treatments reduced ammonia volatilization and proved to be effective in reducing $\mathrm{N}$ losses. A similar ammonia volatilization rate, equivalent to $U+P$, occurred with U+NBPT, a recognized additive capable of reducing volatilization (Dunn and Wiatrak, 2014, Gordon, 2014), allowing these additives to be used as tool to increase the efficiency of nitrogen fertilization. However, efficiency is linked to factors intrinsic to the environment and to the plant (Dupas et al., 2016).

The use of IEF may reduce ammonia volatilization, since some studies reported the low nitrogen use efficiency (NUE), finding values of $36 \%$ (Melgar et al., 1991), 30 to $40 \%$ (Freney et al., 1993), 44 \% (Mattos Junior et al., 2002), 41\% (Chen et al., 2008), 33\% (Arnall et al., 2009), 40 to $60 \%$ (Martínez-Alcántara et al., 2013) and 25.2\% (Cannavo et al., 2013). Increasing the NUE leads to greater use of fertilizer by plants, and there is a possibility of reducing the fertilizer dose and the impact on the environment.

The $\mathrm{N}^{-} \mathrm{NH}_{4}^{+}$content was higher than that of $\mathrm{N}-\mathrm{NO}_{3}{ }^{-}$ throughout the evaluation of the third experiment. 
Table 1. Chemical and physical characterization of the soils used in the experiments.

\begin{tabular}{|c|c|c|c|c|}
\hline & & 10 experiment & 20 experiment & 3ㅇ experiment \\
\hline $\mathrm{C}^{*}$ & $\mathrm{~g} \mathrm{dm}^{-3}$ & 9.88 & 10.27 & 7.44 \\
\hline $\mathrm{N}-\mathrm{NO}_{3}{ }^{-}$ & $\mathrm{mg} \mathrm{kg}^{-1}$ & 13.45 & 1.88 & 14.70 \\
\hline $\mathrm{N}-\mathrm{NH}_{4}^{+}$ & $\mathrm{mg} \mathrm{kg}^{-1}$ & 8.65 & 11.85 & 7.47 \\
\hline $\mathrm{pH} \mathrm{CaCl}{ }_{2}$ & & - & 5.90 & - \\
\hline $\mathrm{pH} \mathrm{H}{ }_{2} \mathrm{O}$ & & 5.40 & - & 6.10 \\
\hline $\mathrm{P}$ & $\mathrm{mg} \mathrm{dm}^{-3}$ & 15.70 & 6.40 & 2.60 \\
\hline K & $\mathrm{mmol}_{\mathrm{c}} \mathrm{dm}^{-3}$ & 10.5 & 1.0 & 1.0 \\
\hline $\mathrm{Ca}$ & $\mathrm{mmol}_{\mathrm{c}} \mathrm{dm}^{-3}$ & 36.0 & 48.5 & 40.2 \\
\hline $\mathrm{Mg}$ & $\mathrm{mmol}_{\mathrm{c}} \mathrm{dm}^{-3}$ & 25.0 & 30.8 & 33.3 \\
\hline $\mathrm{Al}$ & $\mathrm{mmol}_{\mathrm{c}} \mathrm{dm}^{-3}$ & 0.00 & 0.00 & 0.00 \\
\hline $\mathrm{H}+\mathrm{Al}$ & $\mathrm{mmol}_{\mathrm{c}} \mathrm{dm}^{-3}$ & 49.6 & 36.8 & 29.4 \\
\hline СТC & $\mathrm{mmol}_{\mathrm{c}} \mathrm{dm}^{-3}$ & 121.1 & 117.1 & 103.9 \\
\hline V & $\%$ & 59.0 & 68.6 & 71.7 \\
\hline Argila & $\mathrm{g} \mathrm{kg}^{-1}$ & 750 & 770 & 780 \\
\hline Silte & $\mathrm{g} \mathrm{kg}^{-1}$ & 130 & 120 & 140 \\
\hline Areia & $\mathrm{g} \mathrm{kg}^{-1}$ & 120 & 110 & 80 \\
\hline
\end{tabular}
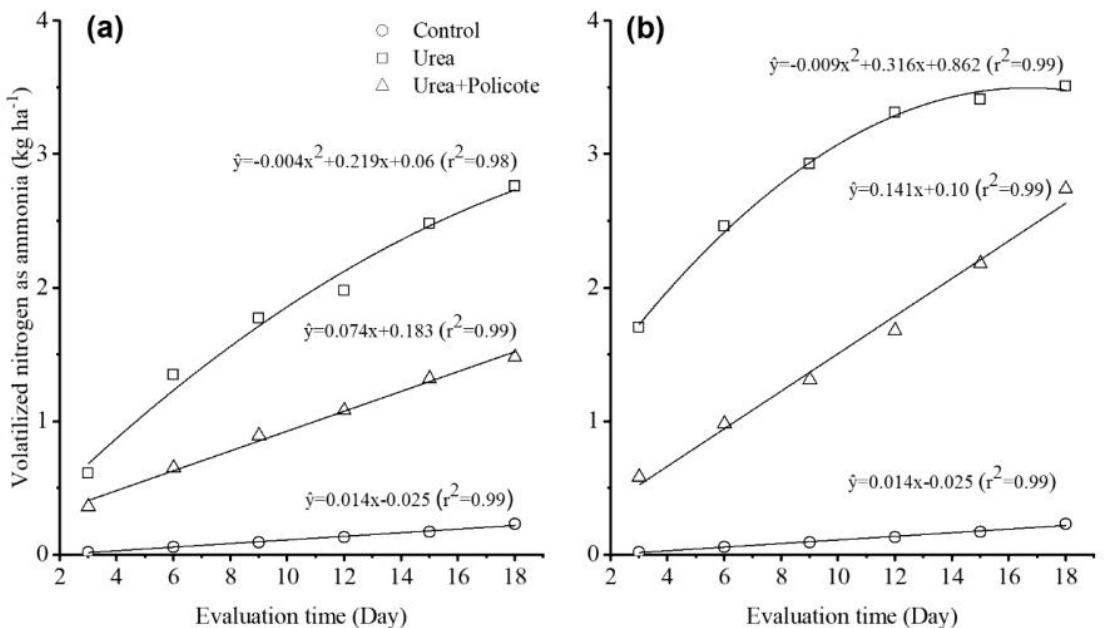

Fig 1. Accumulated volatilization of ammonia $\left(\mathrm{N}-\mathrm{kg} \mathrm{ha}^{-1}\right)$ as a function of days after application of fertilizer doses, (a) nitrogen dose $\left(50 \mathrm{~kg} \mathrm{ha}^{-1}\right)$; and (b) nitrogen dose $\left(100 \mathrm{~kg} \mathrm{ha}^{-1}\right)$.
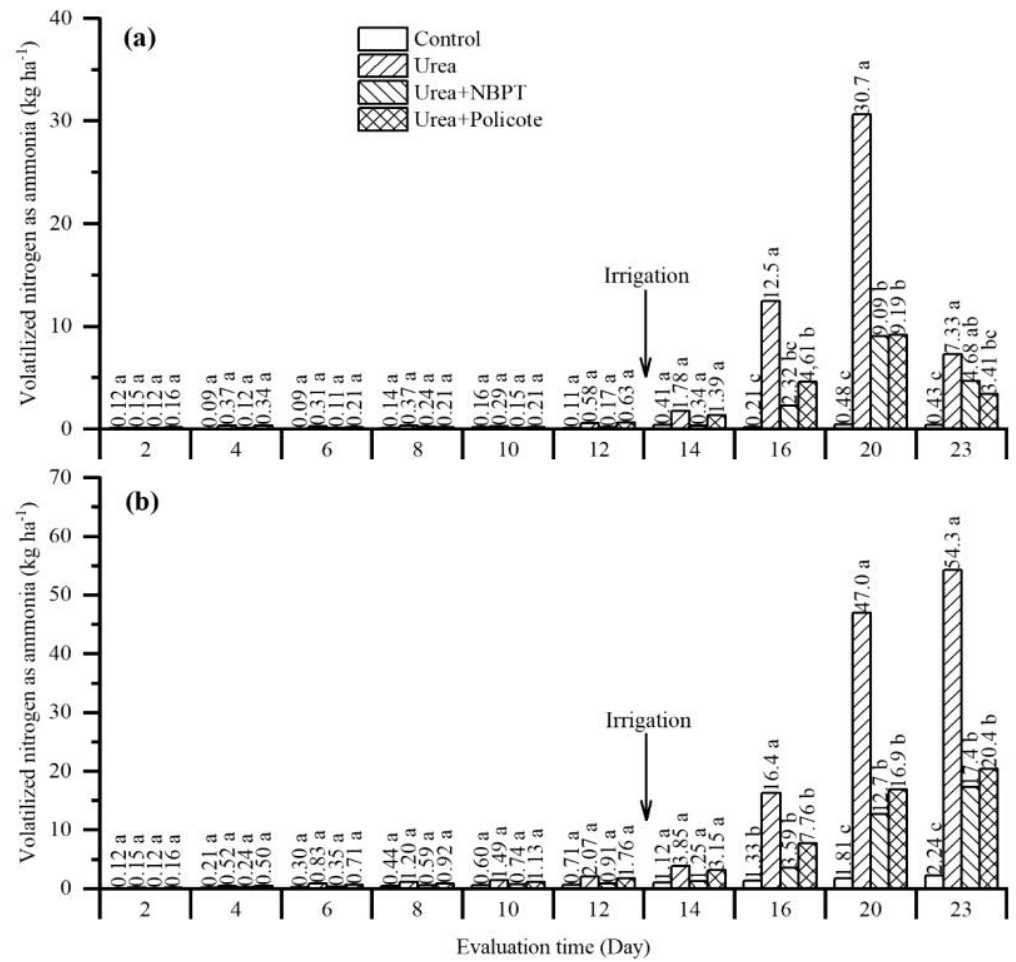

Fig 2. Volatilization of ammonia ( $\mathrm{N}-\mathrm{kg} \mathrm{ha}^{-1}$ ) as a function of days after fertilizer application, (a) non-accumulated values, and (b) accumulated values. Equivalent letters, within each evaluation day, are equal to each other by the Tukey test $(p<0.05)$. 

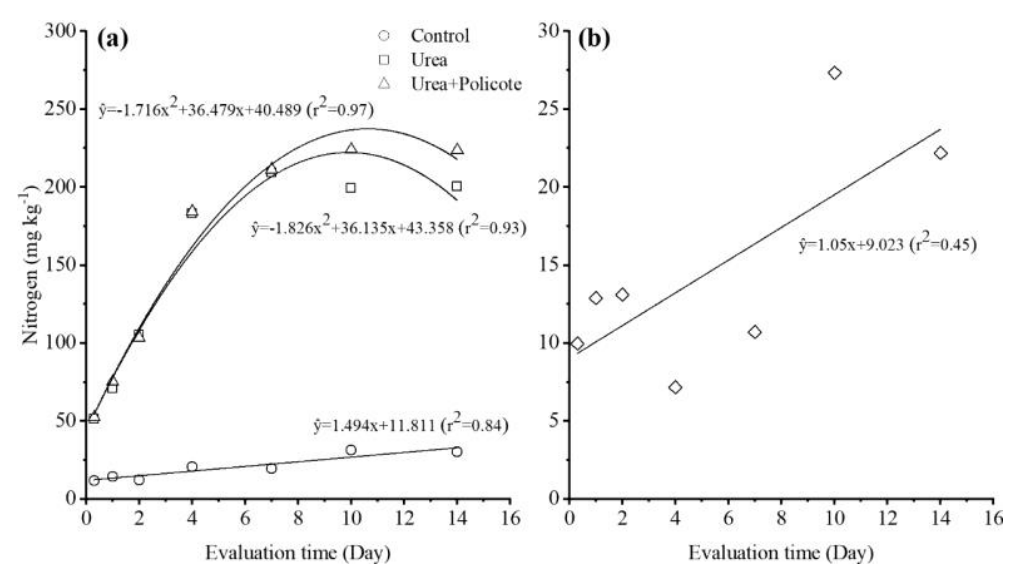

Fig 3. $\mathrm{N}$ content in soil as a function of days after fertilizer application, (a) nitrogen in the ammoniacal form $\left(\mathrm{N}-\mathrm{NH}_{4}{ }^{+}\right)$, and $(\mathrm{b})$ nitrogen in the nitric form $\left(\mathrm{N}-\mathrm{NO}_{3}{ }^{-}\right)$.

However, there are reports that nitrification occurs rapidly in the soil, most of the $\mathrm{N}-\mathrm{NH}_{4}^{+}$applied is nitrified in up to 4 weeks (Paulo, 2012), which did not occur in the present work. It is known that amount of soil organic matter directly affects nitrification (Paulo, 2012). The soil used in this experiment had low organic matter content (Table 1), compromising the nitrification rate. A similar result was observed by Rogeri et al. (2015), in the soil fertilized with urea. The $\mathrm{N}-\mathrm{NH}_{4}{ }^{+}$content was equal to $\mathrm{N}-\mathrm{NO}_{3}{ }^{-}$only after 22 days of fertilizer application.

\section{Materials and methods}

Three experiments were carried out to evaluate nitrogen losses by ammonia volatilization, $\mathrm{N}-\mathrm{NO}_{3}{ }^{-}$and $\mathrm{N}-\mathrm{NH}_{4}{ }^{+}$levels in the soil in response to urea sources. All the experiments were conducted in a controlled environment (greenhouse) located at the IAPAR experimental station.

\section{Characterization of soil and fertilizers}

The three soils used in the experiments were collected in the same agricultural area, cultivated with soybean and corn, at the experimental station of the Instituto Agronômico do Paraná (IAPAR), located in the city of Londrina, Brazil, geographical coordinates S2321'27.34 ", W51이 '32.64 ', altitude $572 \mathrm{~m}$. The soils sampled were of basaltic formation, with a high degree of weathering, and classified as Red Latosol Distroferric (Santos et al., 2013). The mineralogy of the clay fraction was composed of kaolinite, hematite, gibbsite and maghemite. Surface samples of the soils, with 0-20 cm depth, were collected, air-dried, sieved with a 2.0 $\mathrm{mm}$ opening and physically and chemically characterized (Table 1).

The fertilizers used in this work were urea $(45 \% \mathrm{~N})$, urea treated with NBPT $(45 \% \mathrm{~N})$ and Policote-coated urea $(42 \%$ $\mathrm{N})$. The NBPT (N-(n-butyl) thiophosphoric triamide), a urease inhibitor, has been reported as one of the most promising compounds to maximize urea nitrogen use in agricultural systems (Espindula et al., 2014). Policote is an additive based on water-soluble polymers.

\section{Volatilization of ammonia in the soil with high humidity}

The first experiment was conducted to evaluate the volatilization of ammonia in the soil with high humidity after application of sources and doses of urea. The experimental design was formed by a factorial with additional treatment $[(2 \times 2)+1]$ and arranged entirely random with 4 replicates. The factor $A$ was composed of two fertilizers, urea (U) and Policote-coated urea $(U+P)$. The factor $B$ was composed of two doses of nitrogen, 50 and $100 \mathrm{~kg} \mathrm{ha}^{-1}$. Ammonia volatilization was evaluated at $3,6,9,12,15$ and 18 days after fertilizer application. The additional treatment (control) did not receive the addition of the fertilizers. Each experimental unit was formed by a plastic pot $(54.0 \times 33.0$ $\mathrm{cm}$ ) containing a soil layer with $5.0 \mathrm{~cm}$ height.

To maintain soil with high humidity, each experimental unit received an irrigation sheet $(15 \mathrm{~mm})$ of deionized water. The fertilizer was distributed over the entire soil surface in each experimental unit immediately after soil irrigation. A cylindrical chamber $(10,30 \mathrm{~cm}$, diameter and height, respectively) was used to capture volatilized ammonia, containing in its interior, a Falcon tube with $20 \mathrm{~mL}$ of solution (0.05 $\mathrm{M} \mathrm{H}_{2} \mathrm{SO}_{4}$ and $1 \%$ glycerin) and filter paper $(15.0 \times 2.0 \mathrm{~cm})$ with a part immersed in the solution (Marsola et al., 2007). At each evaluation time, the acid solution with the ammonia captured as $\left(\mathrm{NH}_{4}\right)_{2} \mathrm{SO}_{4}$ was stored in an amber flask for further determination. After each evaluation, soil irrigation (sheet $15.0 \mathrm{~mm}$ ) was performed with subsequent installation of the chamber in another position on the experimental unit until the 18th day. The determination of the amount of volatilized ammonia was performed by salicylate blue spectrophotometry (Miyazawa et al., 1992). The volatilized ammonia values were calculated by $\mathrm{kg} \mathrm{ha}^{-1}$ unit, and for each evaluation time the previous evaluations were summed up to obtain the accumulated volatilization of ammonia.

\section{Volatilization of ammonia with dry and low humidity soil}

The second experiment was conducted to evaluate the volatilization of ammonia in initially dry soil and later with low humidity after application of urea sources. The experimental design was formed by a factorial $(4 \times 10)$ and arranged entirely random with 4 replicates. The factor $B$ was composed by the application of nitrogen $\left(150 \mathrm{~kg} \mathrm{ha}^{-1}\right)$ in the form of: urea (U), urea treated with NBPT $(U+N B P T)$, Policote-coated urea $(\mathrm{U}+\mathrm{P})$, and a treatment (control) without nitrogen application. The factor $B$ was composed of 10 periods of evaluation of ammonia volatilization at 2, 4, 6, $8,10,12,14,16,20$ and 23 days after fertilizer application. 
Each experimental unit composed of a plastic pot $(54.0 \mathrm{x}$ $33.0 \mathrm{~cm}$ ) containing a soil layer $5.0 \mathrm{~cm}$ height.

The fertilizer was distributed over the entire surface of the dry soil in each experimental unit. A cylindrical chamber (10 and $30 \mathrm{~cm}$, diameter and height, respectively) were used to capture volatilized ammonia, containing its interior, a falcon tube with $20 \mathrm{~mL}$ of solution ( $0.05 \mathrm{M} \mathrm{H}_{2} \mathrm{SO}_{4}$ and $1 \%$ glycerin) and filter paper $(15.0 \times 2.0 \mathrm{~cm})$ with a part immersed in the solution (Marsola et al., 2007). At each evaluation time, the acid solution with the ammonia captured $\left(\mathrm{NH}_{4}\right)_{2} \mathrm{SO}_{4}$ and stored in an amber flask for further determination. After the exchange of the Falcon tube, the chamber was installed in another position on the experimental unit. This procedure was repeated until the $23^{\text {rd }}$ day. The samples were collected until the $12^{\text {th }}$ day in the dry soil, and immediately after the $12^{\text {th }}$ collection, an irrigation sheet $(5.4 \mathrm{~mm})$ of deionized water was applied, keeping low humidity until the end of the experiment. The volatilized ammonia was determined according to the methodology proposed by Miyazawa et al. (1992).

\section{$\mathrm{N}$-ammoniacal and $\mathrm{N}$-nitric in soil}

The third experiment was conducted to evaluate the ammoniacal and nitric nitrogen content after application of urea sources. The experimental design was formed by a factorial $(3 \times 8)$ and arranged entirely random with 5 replicates. The factor $A$ was composed by the application of nitrogen $\left(200 \mathrm{mg} \mathrm{kg}^{-1}\right)$ in the form of: urea (U), Policotecoated urea $(\mathrm{U}+\mathrm{P})$, and a treatment (control) without application of nitrogen. The factor B was composed of 7 incubation times, $0.3,1,2,4,7,10$ and 14 days after fertilizer application. A plastic container containing $1.0 \mathrm{~kg}$ of soil formed each experimental unit.

The soil was moistened to $60 \%$ of the field capacity ten days before fertilizer application. The fertilizer was homogenized throughout the soil for each experimental unit. Soil samples were collected from each experimental unit after each incubation time. The samples were dried in an $60^{\circ} \mathrm{C}$ oven until constant mass, for later homogenization and extraction with $1.0 \mathrm{M} \mathrm{KCl}+0.05 \mathrm{M} \mathrm{HCl}$ (1:10 soil:extractor ratio). The $\mathrm{N}-\mathrm{NH}_{4}{ }^{+}$content was determined by salicylate blue spectrophotometry (Miyazawa et al., 1992), with $\mathrm{N}^{-} \mathrm{NO}_{3}{ }^{-}$ reduced with metallic $\mathrm{Zn}$. The content of $\mathrm{N}^{-\mathrm{NO}_{3}}{ }^{-}$was calculated by the difference between the contents of $\mathrm{N}^{-} \mathrm{NH}_{4}{ }^{+}$ determined with and without reduction by metallic $\mathrm{Zn}$.

\section{Statistical analyzes}

The data were submitted to analysis of variances (ANOVA) according to each experiment; and when there was significance by the $F$ test $(p \leq 0.05)$ in ANOVA; the mean values of the qualitative variables were analyzed by the Tukey test $(p \leq 0.05)$. For the quantitative variables, the means were adjusted to regression models $(p \leq 0.05)$.

\section{Conclusion}

The volatilization of ammonia was observed by application of Policote-coated urea. This was similar to that observed for urea treated with NBPT and lower than that observed with urea. In dry or very humid soil, the ammonia volatilization rate was low. The reduction of the volatilization of ammonia in the soil with Policote-coated urea was dependent on the humidity, being more effective when the conditions were more propitious to the volatilization of ammonia. The
Policote-coated urea increased the content of $\mathrm{N}-\mathrm{NH}_{4}{ }^{+}$in the soil, compared to urea. The content of $\mathrm{N}^{-\mathrm{NH}_{4}}{ }^{+}$in the soil remained higher than that of $\mathrm{N}^{-\mathrm{NO}_{3}}{ }^{-}$after application of the fertilizers due to the low organic matter content of the soil.

\section{Acknowledgements}

The authors would like to thank the technological cooperation agreement signed between the Instituto Agronômico do Paraná and Wirstchat, which provided technical and financial support for this work.

\section{References}

Arnall DB, Tubaña BS, Holtz SL, Girma K, Raun W (2009) Relationship between nitrogen use efficiency and response index in winter wheat. Journal Plant Nut. 32:502-515.

Association of American Plant Food Control Officials AAPFCO (1997) Official documents 57. West Lafayette: AAPFCO.

Baligar VC, Fageria NK, He, ZL (2001) Nutrient use efficiency in plants. Commun Soil Sci Plant Anal. 32:921-950.

Cabezas WARL, Korndorfer GH, Motta SA (1997) Volatilização de $\mathrm{N}-\mathrm{NH}_{3}$ na cultura de milho: I. Efeito da irrigação e substituição parcial da uréia por sulfato de amônio. R Bras Ci do Solo. 21:481-487.

Cahill S, Osmond D, Weisz R, Heiniger R (2010) Evaluation of alternative nitrogen fertilizers for corn and winter wheat production. Agron J. 102:1226-1236.

Cancellier EL (2013) Eficiência da ureia estabilizada e de liberação controlada no milho cultivado em solo de fertilidade construída. Lavras: UFLA. 75 p. (Thesis).

Cannavo $\mathrm{P}$, Harmand JM, Zeller BP, Vaast $\mathrm{P}$, Ramirez JE, Dambrine E (2013) Low nitrogen use efficiency and high nitrate leaching in a highly fertilized Coffea arabica-Inga densiflora agroforestry system: a ${ }^{15} \mathrm{~N}$ labeled fertilizer study. Nutr Cycl Agroecosyst. 95:377-394.

Carelli MLC, Fahl JI, Ramalho JDC (2006) Aspects of nitrogen metabolism in coffee plants. Braz J Plant Physiol. 18(1):921.

Carvalho MCS, Ferreira GB, Carvalho OS, Silva ORRF, Medeiros JC (2008) Nutrição, calagem e adubação. In: Beltrão NEM, Azevedo DMP O agronegócio do algodão no Brasil. Brasília. Embrapa Informação Tecnológica. 677-790.

Chen D, Suter H, Slam A, Edis R, Freney JR, Walker CN (2008) Prospects of improving efficiency of fertilizer nitrogen in Australian agriculture: a review of enhanced efficiency fertilizers. Austr J Soil Res. 46(4):289 - 301.

Civardi EA, Neto ANS, Ragagnin VA, Godoy ER, Brod E (2011) Ureia de liberação lenta aplicada superficialmente e ureia comum incorporada ao solo no rendimento do milho. Pesq Agropec Trop. 41:52-59.

Dunn DD, Wiatrak P (2014) Evaluation of N additives for improving $\mathrm{N}$ use efficiency of surface applied Urea to dry seeded and permanently flooded Rice. Amer J Agric Biol Sci. 9(3):401-406.

Dupas E, Buzetti S, Rabêlo FHS, Sarto AL, Cheng NC, Teixeira Filho MCM, Galindo FS, Dinalli RP, Gazola RN (2016) Nitrogen recovery, use efficiency, dry matter yield, and chemical composition of palisade grass fertilized with nitrogen sources in the Cerrado biome. Austr J Crop Sci. 10(9):1330-1338

Espindula MC, Rocha VS, Souza MA, Campanharo MC, Pimentel AJB (2014) Urease inhibitor (NBPT) and efficiency of single or split application of urea in wheat crop. Rev Ceres. 61(2):273-279. 
Fan X, Li F, Liu F, Kumar D (2004) Fertilization with a new type of coated urea: evaluation for nitrogen efficiency and yield in winter wheat. J Plant Nutr. 27:853-865.

Freney JR, Keerthisinghe DG, Chaiwanakupt P, Phongpan S (1993) Use of urease inhibitors to reduce ammonia loss following application of urea to flooded rice fields. Plant and Soil. 155/156:371-373.

Garcia PL, Hugo González-Villalba HA, Sermarini RA, Trivelin PCO (2018) Nitrogen use efficiency and nutrient partitioning in maize as affected by blends of controlledrelease and conventional urea. Arc Agron Soil Sci. 1:1-19.

Gordon WB (2014) Management of urea-containing fertilizers for no-tillage corn using nitrogen stabilizers and coated-granule technology. J Plant Nut. 37(1):87-94.

Grespan SL, Dias LE, Novais RF (1998) Crescimento e parâmetros cinéticos de absorção de amônio e nitrato por mudas de Eucalyptus spp submetidas a deferentes relações amônio/nitrato na presença e ausência de fósforo. R Bras Ci do Solo. 22:667-674.

IFA - International Fertilizer Industry Association (2018) IFA database. <http://www.fertilizer.org/>. 11 jul 2018.

Li Q, Yang A, Roelcke M, Chen X, Zhang F, Pasda G, Zerulla W, Wissemeiaer AH, Liu $X$ (2015) Effect of a new urease inhibitor on ammonia volatilization and nitrogen utilization in wheat in north and northwest China. Fi Crops Res. 175:96-105.

McKenzie RH, Pfiffner PG, Middleton AB, Bremer E (2010) Evaluation of polymer-coated urea and urease inhibitor for winter wheat in southern Alberta. Agron J. 102:1210-1216.

Marschner H (1995) Mineral nutrition of higher plants. San Diego: Acad. Press. 889 p.

Marsola, T. Miyazawa M, Pavan MA, Chaves JC (2000) Avaliação da perda por volatilização de amônia do solo da lavoura cafeeira. In: Simp de Pesq dos Cafés do Brasil. Anais.

Martínez-Alcántara AQ, Polo C, Primo-Millo E, Legaz F (2013) Use of nitrification inhibitor DMPP to improve nitrogen uptake efficiency in citrus trees. J of Agr Sci. 5(2):1-18.

Martins SI, Cazetta JO, Fukuda AJF (2014) Condições, modos de aplicação e doses de ureia revestida por polímeros na cultura do milho. Pesq Agropec Trop. 44:271-279.

Mattos Júnior D, Cantarella H, Quaggio JA (2002) Perdas por volatilização do nitrogênio fertilizante aplicado em pomares de citros. Laranja. 23(1):63-270.

Melgar RJ, Smyth TJ, Cravo MS, Sánchez PA (1991) Doses e épocas de aplicação de fertilizante nitrogenado para milho em Latossolo da Amazônia Central. R Bras Ci Solo. 15:289296.

Miyazawa M, Pavan MA, Bloch MF (1992) Análise química de tecido vegetal. IAPAR, Londrina, Circular Técnica 74.

Nelson KA, Paniagua SM, Motavalli PP (2009) Effect of polymer coated urea, irrigation, and drainage on nitrogen utilization and yield of corn in a claypan soil. Agron J. 101:681-687.

Noellsch AJ, Motavalli P, Nelson KA, Kitchen NR (2009) Corn response to conventional and slow-release nitrogen fertilizers across a claypan landscape. Agron J. 101:607614.

Paulo EN (2012) Avaliação do inibidor de nitrificação fosfato 3,4-dimetil pirazol em três solos com gradiente textural, absorção e uso de nitrogênio em plantas de algodão (Thesis). USP. Piracicaba, SP.

Pereira HS, Leão AF, Verginassi A, Carneiro MAC (2009) Ammonia volatilization of urea in the out-of-season corn. $\mathrm{R}$ Bras Ci Solo. 33:1685-1694.

Prando AM, Zucareli C, Fronza V, Oliveira FA, Júnior AO (2013) Características produtivas do trigo em função de fontes e doses de nitrogênio. Pesq Agropec Trop. 43:3441.

Ribeiro VJ, Andrade FV, Souza CHE, Mendonça ES (2016) Volatilization of ammonia in stabilized slow-release nitrogen fertilizer under controlled conditions. Austr J Crop Sci. 10(6):793-798

Rochette $\mathrm{P}$, Angers DA, Chantigny $\mathrm{M} \mathrm{H}$, Gasser $\mathrm{MO}$, Macdonald JD, Pelster DE, Bertrand $\mathrm{N}$ (2013) $\mathrm{NH}_{3}$ volatilization, soil $\mathrm{NH}_{4}{ }^{+}$concentration and soil $\mathrm{pH}$ following subsurface banding of urea at increasing rates. Can J Soil Sci. 93:261-268.

Rogeri DA, Ernani PR, Lourenço KS, Cassol PC, Gatiboni LC (2015) Mineralização e nitrificação do nitrogênio proveniente da cama de aves aplicada ao solo. R Bras Eng Agríc Amb. 19(6):534-540.

Sangoi L, Ernani PR, Lech VA, Clair CR (2003) Lixiviação de nitrogênio afetada pela forma de aplicação da uréia e manejo dos restos culturais de aveia em dois solos com texturas contrastantes. Ci Rural. 33(1):65-70.

Santos HG, Jacomine PKT, Anjos LHC, Oliveira VA, Oliveira JB, Coelho MR, Lumbreras JF, Cunha TJF (2013) Sistema brasileiro de classificação de solos. 3. ed. Rio de Janeiro: Embrapa Solos.

Schwenke GD, Manning W, Haigh B (2014) Ammonia volatilization from nitrogen fertilizers surface-applied to bare fallows, wheat crops and perennial-grass-based pastures on Vertosoils. S Res. 52:805-821.

Shaviv, A (2000) Advances in Controlled Release of Fertilizers. Adv Agron. 71:1-49.

Souza SR, Fernandes MS Nitrogênio. In: Fernandes MS Nutrição Mineral de Plantas. Viçosa: SBCS, 2006. p. 215252.

Wilson ML, Rosen CJ, John F. Moncrief JF (2009) Potato Response to a Polymer-Coated Urea on an Irrigated, Coarse-Textured Soil. Agron J. 101:897-905. doi: 10.2134/agronj2008.0192x 